\title{
Intention Of Entrepreneurship Of The Economic Faculty Students In Surabaya
}

Siti Mujanah ${ }^{1}$

1Program Studi Manajemen Universitas 17 Agustus 1945, Surabaya, Indonesia

\begin{tabular}{l}
\hline ARTICLE INFO \\
\hline Received November 2020 \\
Accepted November 2020 \\
Published December 2020 \\
Keywords: Entrepreneurial \\
Intention, Entrepreneurship \\
Learning, Internal Locus of \\
Control, Perception about, \\
Self Efficacy.
\end{tabular}

\begin{abstract}
This research plans to discover: 1) understudy business enterprise goals studying Economic Education, 2) the impact of observations about pioneering learning, self viability, and inward locus of control on innovative expectations, 3) different elements that impact enterprising aims. This examination is causal acquainted research. The populace in this examination were understudies studying Economic Education who had taken business courses and enterprising practicum, to be specific class of 2018, and who had taken business enterprise courses and were taking business enterprise courses to be specific class of 2018 . Tests in this examination were 131 respondents taken with stratified irregular inspecting proportionate procedure. The instrument utilized in this examination was a survey/poll. Information investigation strategies in this examination utilized various straight relapse investigation. The outcomes demonstrated that: 1) the enterprise expectations of understudies studying Economic Education incorporated into the high class were $37.4 \%$, those incorporated into the high classification were $55.7 \%$, and there were no understudies who had low pioneering aims. 2) There is a positive and noteworthy impact of observations about innovative learning on enterprising expectations. There is a positive and critical impact of self viability on innovative expectations. There is a positive and noteworthy impact of inside locus of control on innovative goals. There is a positive and noteworthy impact of recognitions about enterprising learning, self viability, and inner locus of control together on innovative goals, Relative Contributions discernments about pioneering learning by $20.40 \%$, self adequacy $72.5 \%$, and inside locus of control $7.1 \%$ of innovative expectations. In the interim, the Effective Contribution (SE) recognition variable about enterprising learning was $11.6 \%$, self adequacy $41.2 \%$, and inward locus of control $4 \%$ towards innovative goals. The measure of powerful commitment (SE) of the three free factors to the needy variable is $56.9 \%$ while the staying $43.1 \%$ is impacted by different factors. 3) Other components that impact the business aims of understudies studying Economic Education are financial variables, autonomy, leisure activities, innovativeness, work, opportunity, experience, character, and different elements.
\end{abstract}




\section{Introduction}

One approach to build business enterprise in Indonesia is through business instruction. Instruction is a shrewd answer for decrease joblessness, in light of the fact that with decent training will bring forth great human resources, yet with a huge populace, bringing about aggressive work, bringing about taught joblessness. School graduates should be coordinated and upheld to not exclusively be arranged as occupation searchers yet should be prepared to move toward becoming employment makers and cultivate understudy enterprising soul. In view of BPS (Central Statistics Agency) information with a populace of 252 million, the quantity of lasting nonfarming business people arrived at 7.8 million individuals or $3.1 \%$. Hence the degree of enterprise in Indonesia has surpassed $2 \%$ of the populace, as a base prerequisite for a general public to flourish. However, this is still lower than different nations. With the expanding number of business people in Indonesia it ought to likewise build existing employments so it tends to be an answer for the issue of joblessness[1].

Business enterprise training in tertiary foundations is relied upon to have the option to get ready understudies to be free, in the wake of graduating understudies as alumni are never again centered on getting to be work hunters[2]. An individual's boldness to enterprise is frequently determined by inspiration from teachers who give viable and alluring enterprise courses, with the goal that it can stir understudies' enthusiasm to begin business enterprise[3].

The distinction in business enterprise learning in the Economics Study program with other investigation projects is that Economic Education expects understudies to take business realizing which comprises of business courses in the third semester with two semester credit units (SKS) and is supplemented by pioneering practicum picking up comprising of business enterprise practicum courses in fourth semester with two semester credit units (SKS). The point of the enterprise courses in the Economic Education study program as portrayed in the prospectus is to assemble innovative inspiration, shape pioneering character/mentality, comprehend the idea of business, and practice pioneering aptitudes.

The goals of the enterprise practicum course are to fabricate character, encourage inspiration and train innovative abilities and prepare understudies on the best way to educate business. In the event that the destinations of the business courses just as the enterprise practicum courses can be accomplished, the normal final product is the development of understudy pioneering conduct[4]. The more genuine encounters understudies have, the more exercises can be deciphered legitimately by understudies. The experience trains understudies to distinguish openings and how to accept the best open doors out of different chances[5]. One pointer of accomplishment in learning enterprise courses is the graduated class of instructive organizations that present enterprise subjects/courses that have taken an interest in the enterprise learning process in the foundation concerned, is relied upon to have an innovative soul and in any event $40 \%$ of graduated class can start autonomous organizations or accomplice.

Research on pioneering goals has been broadly done by specialists. Enterprising expectations can be affected by character and natural components[6]. Character components comprise of requirement for accomplishment, locus of control, and self 
adequacy. Self adequacy also significantly affects innovative expectations[7]. The expectation of business is essentially affected by character factors, one of which is the interior locus of control, to be specific the conviction that achievement and disappointment that happen in life rely upon oneself[8]. Another factor impacting pioneering goals is enterprise training, instruction is significant for business visionaries getting a degree, however instruction likewise has an enormous job in defeating issues in business[9].

Another examination result, self adequacy is demonstrated to intervene business enterprise training and family condition towards innovative interests, these outcomes show that the presence of enterprise courses has encouraged a feeling of trust in understudies to move toward becoming business visionaries[5]. The modest number of alumni of the Department of Economic Education who have enterprise is dreaded to be brought about by an inspiration procedure that isn't yet adequate, while when understudies have taken business courses, understudies have pioneering expectations at the level being expected that the aims are not passed on to conduct, with the goal that the aim stops just getting to be unrealistic reasoning[8]. That is the reason specialists need to discover how far understudies 'enterprising expectations are and how much impact the elements of pioneering goals are understudies' impression of innovative learning, self-adequacy, and inner locus of control of enterprising aims in Economics Students. In light of the the foundation, the scientist is keen on leading further research on factors influencing the pioneering goals of economic education students.

\section{Research Methods}

This research is an associative type of research. Associative research is research that aims to determine the relationship of two or more variables. This study uses a quantitative approach because the information in this study is centered on numbers (amount) and the management of information uses descriptive statistical analysis to arrive at the conclusions of the research results. Quantitative methods can be interpreted as research methods based on the philosophy of positivism, used to examine populations or specific samples, sampling techniques are generally carried out arbitrarily, information collection using research instruments, information analysis is quantitative/statistical in order to test the hypothesis that has been set. The statistical analysis used is descriptive statistical analysis and inferential statistical analysis.

Descriptive statistical analysis is used to describe or provide an overview of research subjects, specifically students of Economics in East Java Province who have taken entrepreneurship courses and entrepreneurial practicum, which is class of 2018, and students who have taken entrepreneurial courses and are taking entrepreneurial practicum courses as a research sample without any intention of drawing broader conclusions (generalizations/inferences). Meanwhile, inferential statistical analysis is used to analyze information samples taken arbitrarily, then from the results of the analysis a conclusion is drawn to further generalize (referenced) for all students of Economic Education. This study was developed with a cross-sectional model in which the researcher only made observations at one time carried out simultaneously by distributing questionnaires to research subjects to obtain preliminary information. 


\section{Result and Discussion}

Theoretical framework and hypotheses: Intention of Entrepreneurship: Expectation is characterized as a person's abstract likelihood measurement in connection to self and conduct. Intention is an individual's estimation of the fact that it is so prone to make a specific move. Expectation is a segment in a person that alludes to the craving to play out specific practices [3]. The development of expectations can be clarified by arranged conduct hypothesis which accept people consistently have objectives in conduct and as a rule the aim precursor elements can be communicated through Theory Planned Behavior (TPB) comprising of inside and outside elements [6]. Inward factors comprise of convictions or social demeanors, abstract standards and conduct control. There are three essential determinants, in particular:

1. Attitude Toward Behavior (Attitude to Behavior)

Disposition toward a conduct is a capacity that depends on convictions called social convictions, specifically singular convictions about the positive or negative outcomes that people will get from playing out a conduct. Specifically in the hypothesis of arranged conduct, dispositions toward conduct are characterized as the level of positive or negative evaluation of people towards a conduct. Frames of mind toward conduct are controlled by a mix of individual convictions and individual emotional qualities in regards to the positive or potentially negative results of a conduct[9].

\section{Subjective Norms}

Abstract standards are characterized as individual recognitions about the perspectives on those nearest to a specific behavior. The perspectives on individuals nearest to you, for example, family, companions, and associates with respect to help or dismissal of a conduct will cause social weight felt by somebody and will influence one's judgment in doing the conduct being referred to[2].

3. Behavioral control

Conduct control is a person's impression of the control he has regarding certain practices, control here identifies with faith in the degree of trouble in doing certain practices as per their abilities. In some pioneering examinations, conduct control is operationalized as self adequacy[1].

Entrepreneurship: Business enterprise is a capacity to oversee something that exists in a distinct individual to be used and demonstrated to be increasingly ideal (great) so it can improve the way of life of people later on. Business is the eagerness and capacity of an individual to manage different dangers by taking activities to make and do new things using a blend of different assets with the point of giving the best support everything being equal (partners) and get benefits as a result[4]. Business enterprise is the way toward experimenting and distinctive with the point of making flourishing for people and enhancing society. Business is the procedure of creating something different utilizing time and exertion joined by capital and hazard and getting prizes and fulfillment and individual flexibility[5].

From a portion of the clarifications above, it tends to be reasoned that business enterprise is the procedure of ideally utilizing existing assets with specific dangers so as to accomplish thriving for people and society[9]. In this way it very well may be comprehended that the goal picture originates from existing reality and furthermore 
tastes, from psychosensible conditions. Goal picture can be estimated through two markers to be specific (1) intellectual picture is a feeling of certainty and a lot of data controlled by sightseers about a vacation spot and (2) full of feeling picture is a passionate feeling of a visitor towards a vacation spot.

Entrepreneurship Course Learning: Learning is to instruct understudies to utilize the standards of training and learning hypothesis which are the primary discourage minants of instructive achievement. Learning is a twoway correspondence professional cess, instructing is completed by the instructor as a teacher, while learning is done by understudies or understudies[3]. Learning is basically a procedure of collaboration between the instructor and understudies, and the encompassing condition, which in the process there is a push to improve the nature of understudies themselves better than anyone might have expected. Learning infers each movement that is intended to enable somebody to get familiar with another capacity as well as worth. Get the hang of learning is a procedure of conveying learning, which is completed utilizing the inconvenience strategy, by emptying information into understudies[4].

From the meanings of the specialists above it tends to be reasoned that innovative learning is a progression of exercises intended to show business enterprise hypothesis and practice to understudies, with direction from teachers and has the objective that understudies have the capacities and character of business people. The motivation behind learning is the authority of information that originates from the arrangement of subjects conveyed at school[5]. The arrangement of subjects is as different encounters that originated from guardians previously and that occurred in human life.

These encounters are portrayed, organized and distributed in course readings from different mean. Entrepreneurship learning is an external factor that influences entrepreneurial intentions. Empirical studies on the role of learning in increasing entrepreneurial intentions are increasingly widespread by researchers around the world. By introducing the concept of entrepreneurship through entrepreneurship learning, it can stimulate students' interests and desires for entrepreneurship. A better understanding of entrepreneurship will increase student entrepreneurship intentions[8].

Self Efficacy: Self adequacy is a person's dynamic faith in his capacity to be equipped in completing certain assignments or arrangement of exercises[3]. Self viability can be characterized as a person's confidence in his capacity to play out specific assignments at a specific level, or an individual's conviction that he can make a move to accomplish a specific result. Self viability as an individual's evaluation of himself or his capacities identified with his activities. In view of the above comprehension, it tends to be presumed that self- viability in business is one's conviction or judgement about the capacities had, in regards to how much exertion he can do in finishing certain undertakings to turn into an entrepreneur[4].

Internal Locus of Control: Locus of control is an image of an individual's convictions about the determinants of his conduct. Locus of control is an occasion experienced by somebody as a reward or fortification, can be seen distinctively and furthermore cause various responses in every person. Locus of control likewise characterizes as a proportion of an individual's general assumptions about control of fortification. Locus of control is individual command over work and trust in self- 
achievement[3]. From the depiction above it tends to be presumed that the locus of control is the degree of individual conviction about control that decides the achievement or disappointment that happens in him.

The Effect of Entrepreneurship Learning Perception on Entrepreneurial Intention: Business enterprise learning is a progression of exercises intended to show enterprise hypothesis and practice to scratches, with direction from instructors and has an objective so understudies' capacities and character of business visionaries[7]. The point of enterprise learning is to shape understudies to move toward becoming people who have innovative character and conduct, on the grounds that in a more extensive sense, business enterprise isn't just about exchanging, yet business is a predominant character that understudies ought to have with the goal that they can later turn into the country's age developers. Business visionaries carry numerous advantages to the nation since they drive the economy as far as generation, circulation and utilization. Being an entrepreneur means opening work open doors for the network, in order to diminish joblessness. The primary character of business enterprise is inventive, creative, and hazard taking. In this manner, the speculation can be closed as pursues:

\section{H1 : Entrepreneurship Learning Perception Influences Entrepreneurial Intention}

Effect of Locus of Control on Entrepreneurial Intention: Locus of control is the degree of individual conviction about control that decides achievement or disappointment that happens in him. There are two sorts of locus of control, in particular inner locus of control and outer locus of control[8]. Inner locus of control is one's conviction that what decides achievement is oneself, so people who have internal locus of control will in general be persevering and free, while people with outside locus of control have the conviction that achievement is deflect mined by the earth or fate or different things, not in view of the exertion he did himself. In the event that it is identified with the character of business that isn't anything but difficult to surrender and constantly sure, at that point people who have an inward locus of control positively additionally have high pioneering goals[2]. Since the individual believes in his solidarity to have the option to make progress with the goal that he will consistently attempt to make progress by proceeding to attempt regardless of disappointments, the endeavors made constantly will shape a conduct, this is a normal for individuals who have high innovative aims[1]. Along these lines, the theory can be finished up as pursues:

\section{H2 : Locus of Control Influences the Entrepreneurial Intention}

The Effect of Entrepreneurial Self Efficacy on Entrepreneurial Intention: Self adequacy with regards to business enterprise is an individual's conviction or judgment about the abilities he has, about how much exertion he can do in finishing certain errands to turn into a business visionary[6]. Self viability incorporates significant personality factors and when joined with explicit objectives, for this situation the proposed reason for existing is to turn into a business visionary. To be a business visionary requires solid self-assurance in managing all circumstances, this certainty is showed as self adequacy[9]. Every individual has an alternate degree of self viability in various circumstances relying upon the capacity to request, the nearness of other individuals or rivals, physiological and enthusiastic conditions, for example, uneasiness, discouraged, 
tired, etc. At the point when looked with troubles, understudies who have high innovative self viability will attempt to conquer these difficulties.

Understudies who have high pioneering self-viability will concentrate and spend more exertion on the circumstance they face, and any snags that emerge will urge them to invest much more energy. Consequently, understudies who have high pioneering self adequacy are required to want to move toward becoming business visionaries or what is alluded to as innovative goals[7]. Innovative goals alluded to in this setting are aims that have been understood that are passed on to pioneering conduct. In light of the portrayal above it very well may be accepted that self viability significantly affects pioneering goals. In this manner the accompanying theories can be drawn:

3. H3 : Self Efficacy Entrepreneurship impacts enterprising expectations

The Influence of Perception on Learning Entrepreneurship, Locus of Control, and Self Efficacy of Entrepreneurship on the Entrepreneurial Intention: An individual's conduct for business does not emerge without anyone else's input. Numerous examinations that clarify that enterprising intentions are really impacted by numerous variables, both inside and outside elements. In this examination, it will be watched the impact of aims of inward factors as locus of control and self viability, and saw from outer factors, to be specific the view of innovative learning[4]. The outer factor of pioneering expectations that will be inspected in this investigation is understudies' view of entrepreneurial learning. Recognition is a perception of an item or occasion that is handled into the mind through the five detects which is then gotten by the understanding of the article or occasion[6].

Economic department students will have various impression of learning business enterprise courses despite the fact that the strategies and learning materials gave are the equivalent in a class[5]. Business enterprise learning is a progression of exercises intended to show business hypothesis and practice to understudies, with direction from instructors and has the objective that understudies have the capacities and character of business visionaries[7]. After understudies have learned business, understudies are relied upon to have a positive impression of innovative capacities in order to bring high enterprising expectations. In this way the accompanying speculations can be drawn:

4. H4 : Entrepreneurship Learning Perception, Locus of Control, and Self Efficacy of Entrepreneurship impacts the Entrepreneurial Intention.

Result: based on the results of the research discussion and conclusions drawn in this study, the following implications can be presented as this study reveals that there is a positive influence of perceptions about entrepreneurial learning on student entrepreneurship intentions, so the implications of entrepreneurial learning must lead to practice, thus educators should have empirical experience in doing business, so what is conveyed during learning is a real experience in the field. This research reveals that there is a positive effect of self efficacy on student entrepreneurship intentions, so the implication is that high confidence is needed to be an entrepreneur, students must have the courage to take risks and read business opportunities, this can be achieved if during running a student company, a diligent student and serious about running his business. This study reveals that there is a positive internal locus of control effect on student entrepreneurship intentions, so the implication is that students must be willing to work 
hard to achieve success, this can be achieved by changing students mind sets about success, that success can achieved with effort.

\section{Conclusion}

Based on the discussion of the above research results, the writer tries to give some suggestions. First, there are still students who have enough entrepreneurial intentions, therefore the Economic Education study program is expected to be more active in maintaining and increasing student entrepreneurship intentions. That way, entrepreneurship intentions that are still in the sufficient category can increase to high. Entrepreneurship learning on campus should be maintained the quality of the learning process, improve entrepreneurial learning facilities available such as places of business and capital, and improve learning media so that students feel enthusiastic when learning takes place and are able to absorb knowledge well.

Second, judging from the factor of self efficacy there are still students who have sufficient self efficacy, therefore students need to build confidence by reading inspirational figures and psychology books, because the ability to manage motivation and emotions is also important to be made into an entrepreneur. Third, judging from the internal locus of control factors, there are still students who have low internal locus of control. Therefore, guidance from educators is needed so that students have good control of their environment so as to improve internal locus of control. Finally, researchers can further develop research on factors of entrepreneurial intentions because there are still $27.39 \%$ of other variables that can affect the entrepreneurship intentions of students of economic education in East Java Province in addition to the variables that have been examined in this study.

\section{References}

[1] A. Vahabzadeh, H. Vatanpour, R. Dinarvand, A. Rajabzadeh, J. Salamzadeh, and M. Mohammadzadeh, "Impact of corporate reputation on brand differentiation an empirical study from Iranian pharmaceutical companies," Iran. J. Pharm. Res., vol. 16, no. 4, pp. 1658-1670, 2017, doi: 10.22037/ijpr.2017.2128.

[2] N. Y. Jung and Y. K. Seock, "The impact of corporate reputation on brand attitude and purchase intention," Fash. Text., vol. 3, no. 1, 2016, doi: 10.1186/s40691-0160072-y.

[3] C. Nam, H. Dong, and Y. A. Lee, “Factors influencing consumers' purchase intention of green sportswear," Fash. Text., vol. 4, no. 1, 2017, doi: 10.1186/s40691017-0091-3.

[4] M. R. Jalilvand and N. Samiei, "The Effect of electronic Word of Mouth on Brand Image and Purchase Intention: An Empirical Study in The Automobile Industry in Iran," Mark. Intell. Plan., vol. 30, no. 4, pp. 460-476, Jun. 2012, doi: 10.1108/02634501211231946.

[5] Santoso, Rudi; Shinta, Rahayu; Fianto, Achmad Yanu Alif. Pengaruh Bauran Pemasaran Jasa Terhadap Keputusan Berkunjung Ke Wisata Bahari Jawa Timur. Jurnal MEBIS (Manajemen dan Bisnis), 2019, 4.2: 73-86.

[6] J. M. T. Balmer and S. A. Greyser, "Corporate Brands with a Heritage - Bradford University School of Management Working Paper," Bradford, 2007. 
[7] B. Ranjbarian, A. Sanayei, M. R. Kaboli, and A. Hadadian, "An Analysis of Brand Image, Perceived Quality, Customer Satisfaction and Re-purchase Intention in Iranian Department Stores," Int. J. Bus. Manag., vol. 7, no. 6, Mar. 2012, doi: 10.5539/ijbm.v7n6p40.

[8] Fianto, Achmad Yanu Alif. Satifaction As Intervening For The Antecedents Of Intention To Revisit: Marine Tourism Context In East Java. Relasi: Jurnal Ekonomi, 2020, 16.1: 179-207.

[9] T. Djatmiko and R. Pradana, "Brand Image and Product Price; Its Impact for Samsung Smartphone Purchasing Decision," Procedia - Soc. Behav. Sci., vol. 219, pp. 221-227, 2016, doi: 10.1016/j.sbspro.2016.05.009. 